\title{
PENGARUH METODE ASSESMENT PROSES KONTROL MENINGKATKAN KETERAMPILAN BERPIKIR KRITIS MELALUI PEMBELAJARAN
}

\author{
Siti Mayang Sari ${ }^{1}$,Chairul Fauzi ${ }^{2}$, Winning Amintas Kartika Waruwu ${ }^{3}$, \\ Hasratuddin ${ }^{4}$ \\ ${ }^{1}$ STKIP Bina Bangsa Getsempena Meulaboh, Indonesia., ${ }^{2}$ Sekolah Tinggi Ilmu \\ Hukum Muhammadiyah Takengon, Indonesia., 3.Akper KESDAM I/BB Medan, , \\ Indonesia., ${ }^{4 \cdot}$ Universitas Negeri Medan, Indonesia. \\ Email: $\underline{\text { Sitimayangsari30@gmail.com }{ }^{1}, \text { khairulfauzi94@gmail.com }{ }^{2} \text {, winningwaruwu95@gmail.com³ }}$, \\ siregarhasratuddin@yahoo.com ${ }^{4}$
}

\begin{abstract}
Writing this article, it describes a process control assessment method that will improve students' critical thinking skills. This study uses a quantitative research method where data processing is based on multivariate analysis, where this method aims to find out how much influence the variables on an object, or in large numbers simultaneously or simultaneously. A control analysis process that results from the final grades of T / A students 2013-2019, is expected to get better and simultaneous learning value results, so that it will improve critical thinking skills for students. With regard to this value, it can be seen from the results of the process of statistical multivariate analysis based on the results of the final scores of five courses, namely: Indonesian Language, Learning Strategies, Aqidah Akhlak, Learning Psychology, and Early Childhood Education Development. Multivariant analysis reveal will that the process of assessing the results of data from student scores can be used as a reference for other students in different subjects, to be able to maintain their final score results by having the potential in learning innovation, namely having critical thinking skills and for eye-level lecturers. The lecture can see the level of student achievement in the last seven years.
\end{abstract}

Keywords: Assessment Method, Proses control, Learning, Critical Thingking.

\begin{abstract}
ABSTRAK
Penulisan artikel ini menjelaskan metode penilaian pengendalian proses yang akan meningkatkan keterampilan berpikir kritis siswa. Penelitian ini menggunakan metode penelitian kuantitatif dimana pengolahan datanya didasarkan pada analisis multivariat, dimana metode ini bertujuan untuk mengetahui seberapa besar pengaruh variabel terhadap suatu objek, atau dalam jumlah yang besar secara simultan maupun simultan. Proses analisis kendali yang dihasilkan dari nilai akhir siswa T / A angkatan 2013-2019 diharapkan mendapatkan hasil nilai belajar yang lebih baik dan simultan, sehingga akan meningkatkan kemampuan berpikir kritis siswa. Berkenaan dengan nilai tersebut dapat dilihat dari hasil proses analisis statistik multivariat berdasarkan hasil nilai akhir lima mata kuliah yaitu: Bahasa Indonesia, Strategi Pembelajaran, Aqidah Akhlak, Psikologi Pembelajaran, dan Pendidikan Anak Usia Dini. Pengembangan. Analisis multivarian mengungkapkan akan proses penilaian data hasil nilai siswa dapat dijadikan acuan bagi siswa lain pada mata pelajaran yang berbeda, untuk dapat mempertahankan hasil nilai akhir mereka dengan memiliki potensi dalam inovasi pembelajaran yaitu berfikir kritis. keterampilan dan untuk dosen tingkat mata. Perkuliahan dapat melihat tingkat pencapaian mahasiswa dalam tujuh tahun terakhir.
\end{abstract}

Kata kunci : Metode penilaian, kontrol Proses, Belajar, Berpikir Kritis

\section{PENDAHULUAN}

Assesmen yaitu penilaian, sedangkan metode assesmen dalam pendidikan memiliki pengertian kegiatan mengumpulkan data nilai, menganalisis data nilai, dan menginterpretasi data atau informasi tentang penilaian peserta didik dan lingkungannya untuk memperoleh gambaran tentang kondisi individu dan lingkungannya sebagai bahan untuk memahami perkembangan individu dan pengembangan program layanan bimbingan dalam pembelajaran yang sesuai dengan kebutuhan, (Wasikin Haryanti, 2017). Generasi unggul yang dibutuhkan adalah generasi yang memiliki kemampuan 
berpikir kritis, jujur, bermartabat serta mampu menghadapi kehidupan dimasa mendatang, dan dapat bertahan hidup secara manusiawi serta percaya diri, (Hasratuddin, 2013).

Diketahui bahwa dosen di setiap pengampu matakuliah kesulitan memberikan metode belajar yang efektif pada bimbingannya terkait menilai dan memberi penilaian. Disebabkan matakuliah yang bervariasi dan mahasiswa dituntut untuk mengikuti setiap matakuliah yang diemban. Dilihat dari hasil nilai ujian akhir mahasiswa dari tahun 2013-2019 belum terjadi peningkatan yang signifikan. Upaya meningkatkan keterampilan berpikir kritis mahasiswa, maka diupayakan tahun 2020 akan terjadi lonjakan nilai yang signifikan dengan berkembangnya pengetahuan dan inovasi belajar yang lebih baik. Implementasi kurikulum 2013 secara maksimal perlu adanya peningkatan soft skill dan hard skill baik bagi dosen dan mahasiswa, (Kahar, 2018). Terkait masalah tersebut maka peneliti menguraikan tentang pengaruh assessment pada tahun ajaran 2013-2019, apakah berpengaruh nilai mahasiswa di lima tahun tersebut dengan matakuliah lainnya di setiap semester? Apakah terjadi peningkatan pada tahun ajaran selanjutnya pada matakuliah yang sama atau yang lainnya.

Pembelajaran dapat diartikan sebagai proses belajar yang dibangun dari pendidik dalam mengembangkan potensi kreatifitas berpikir anak didik agar dapat meningkatkan kemampuan berpikir dalam pemecahan masalah, serta dapat meningkatkan kemampuan dalam mengkortuksikan pengetahuan barunya, sehingga memiliki kualitas dan hasil yang maksimal, (Amalia et al., 2017). Tujuannya dari penelitian ini adalah untuk meninjau apakah hasil penilaian dosen yang di lihat dari hasil belajar mahasiswa dapat di pertahankan atau harus mendapatkan inovasi produk pembelajaran terbaru dan memiliki pengaruh antara pelajaran satu dengan yang lainnya, sehingga hasil belajar mahasiswa pada lima matakuliah di semester 2 pada tahun 2020 akan terjadi penyesuaian terhadap program pembelajaran dari dosen pengampu tersebut.

Upaya untuk peningkatan mutu proses pembelajaran dan mencapai keluaran yang berkualitas terus diupayakan oleh berbagai pihak dalam pendidikan, upaya ini dengan sendirinya harus diartikan sebagai upaya perbaikan dalam pendidikan serta pembelajaran yang bermutu serta berkualitas, (Aziz, 2015). Peran utama pengajar adalah mencetak para pembelajar yang handal (powerful leaners), (Tabrani, 1989 ; Darmadi, 2015). Sejalan dengan upaya meningkatkan mutu dan kualitas pembelajaran, maka sangat penting untuk menganalisis data nilai mahasiswa yang bersangkutan berdasarkan assessment persemester. Berdasarkan data autentik dari beberapa dosen pengampu lima mata kuliah di Universitas Alwashliyah Medan, maka akan menjadi suatu acuan untuk lebih baik kedepannya.

Permasalahan yang akan diangkat dalam tulisan ini adalah apakah terdapat hubungan antara satu mata kuliah dengan mata kuliah yang lain dengan menggunakan metode assessment dengan analisis statistik multivariant? Apakah hasil analisis control proses pembelajaran dapat berjalan dengan sempurna?. Tujuan dari penulisan terkait dengan permasalahannya adalah mengetahui hubungan dan keterkaitan antara matakuliah satu dengan matakuliah lainnya, dengan adanya kreatifitas berfikir siswa dalam menyelesaikan permasalahan dengan program pembelajaran inovatif dari dosen. Memiliki kemampuan berpikir kritis dapat membantu meningkatkan sikap dan prilaku rasional, (Hasratuddin, 2013).

\section{METODE PENELITIAN}

Metode penelitian yang digunakan adalah kuantitatif dengan pendekatan analisis Multivariant yaitu motode dalam pengolahan variabel dalam jumlah yang lebih daripada dua variabel, tujuan dari metode ini adalah untuk mengetahui apakah variabel-variabel tersebut memiliki pengaruh terhadap suatu objek secara simultan atau serentak, 
(Santoso, 2018). Penulisan artikel ini menjelaskan tentang analisis proses control terhadap assesment mahasiswa pada tujuh tahun terakhir, yaitu tahun 2013 sampai 2019.

Metode analisis multivariant adalah metode statistik yang digunakan untuk menganalisis data yang tersiri dari beberapa variabel dan saling berhubungan satu dengan yang lainnya. ${ }^{3}$ Berdasarkan dari definisi tersebut, maka dapat disimpulkan bahwa dengan menggunakan analisis multivariant ini dapat menganalisis data yang melibatkan beberapa variabel, (Ghozali, 2013).

Hubungan antar dua variabel atau lebih itu bila dilihat dari arahnya dapat dibagi menjadi dua, yaitu hubungan yang sifatnya searah dan berlawanan arah. Hubungan searah disebut korelasi positif, sementara yang berlawanan arah disebut korelasi negatif, (Untersucher et al., 1988). Dimana terdapat satu variabel terikat dan terdapat lebih dari satu variabel bebas, serta terdapat korelasi atau saling keterkaitan antara satu variabel dengan variabel lainnya. Maka dapat dijelaskan kembali bahwa analisis Multivarian merupakan analisis yang melibatkan bagaimana menghitung data secara kompleks, yang tujuannya ialah agar dapat memahami struktur data yang berdimensi tinggi dan saling keterkaitan satu dengan yang lain, Jika terdapat (variabel x) mengalami kenaikan, maka akan diikuti kenaikan (variabel y) Itulah korelasi positif, (Untersucher et al., 1988).

\section{HASIL DAN PEMBAHASAN}

Populasi yang disajikan untuk menyelesaikan analisis ini adalah data autentik dari data nilai UAS mahasiswa Universitas Alwashliyah Medan, Tahun Ajaran 2013, dengan mata kuliah Bahasa Indonesia sebanyak 91 mahasiswa, tahun 2014 sebanyak 95 mahasiswa, tahun 2016 sebanyak 97 mahasiswa, tahun 2017 sebanyak 101 mahasiswa, tahun 2018 sebanyak 99 mahasiswa, tahun 2019 sebanyak 104 mahasiswa, dan sebagai sampel dari ke 5 MK adalah 50 mahasiswa pada setiap Tahun ajaran. Analisis ini berfokus pada: 1) seberapa keterkaitan hasil nilai UAS mahasiswa dengan matakuliah lainnya. 2) apakah terjadi proses kontrol pada setiap matakuliah yang diampu oleh dosen bersangkutan dalam upaya meningkatkan berfikir kritis, 3) upaya dosen memberikan metode belajar yang efisien dalam menyelesaikan masalah.

Diketahui untuk menjalankan pembelajaran dosen harus memiliki program dan metode belajar dalam satu semester. Langkah-langkah pembelajaran yang akan dicapai dengan mutu dan kualitas yang baik serta terorganisir. Data autentik yang dianalisis pada bagian ini adalah nilai skor UAS mahasiswa sejak tahun 2013 sampai 2019 pada lima mata kuliah, antara lain: (X1) Bahasa Indonesia, (X2) Strategi pembelajaran, (X3) Akidah Akhlak, (X4) Psikologi Belajar, (X5) Perkembangan Pendidikan Anak Usia Dini, berjumlah 250 mahasiswa. Dari hasil perhitunyan rata-rata diperoleh dari masingmasing hasil data sebagai berikut.

Tabel 1. Perbandingan Rata-rata 5 mata kuliah

Perincian pada setiap MK sebagai berikut dengan Sampel 50 Mahasiswa.

Perhitungan Nilai dari tahun 2013-2019 dengan 50 Mahasiswa

\begin{tabular}{|c|c|c|c|c|c|}
\hline $\mathrm{No}$ & $\mathrm{X} 1$ & $\mathrm{X} 2$ & X3 & $\mathrm{X} 4$ & $\mathrm{X5}$ \\
\hline 1 & 90,20 & 84,90 & 89,32 & 83,76 & 82,44 \\
\hline 2 & 81,00 & 84,70 & 89,14 & 83,73 & 82,49 \\
\hline 3 & 84,20 & 84,70 & 89,15 & 83,50 & 82,77 \\
\hline 4 & 90,70 & 84,60 & 89,13 & 83,17 & 82,62 \\
\hline 5 & 90,00 & 84,60 & 89,20 & 83,11 & 82,67 \\
\hline 6 & 90,00 & 84,40 & 88,98 & 83,40 & 82,53 \\
\hline 7 & 90,00 & 84,10 & 89,64 & 83,48 & 82,16 \\
\hline 8 & 70,00 & 83,80 & 89,86 & 83,33 & 82,67 \\
\hline 9 & 90,00 & 84,10 & 89,86 & 83,40 & 82,50 \\
\hline 10 & 90,00 & 84,70 & 90,10 & 83,02 & 82,10 \\
\hline
\end{tabular}


JURNAL ILMIAH AQUINAS

http://ejournal.ust.ac.id/index.php/Aquinas/index
p-ISSN: 2615-7683

e-ISSN: 2714-6472

\begin{tabular}{|c|c|c|c|c|c|}
\hline 11 & 90,00 & 84,80 & 89,88 & 82,95 & 82,40 \\
\hline 12 & 90,00 & 84,70 & 89,64 & 82,77 & 82,46 \\
\hline 13 & 90,00 & 84,60 & 89,39 & 82,34 & 82,79 \\
\hline 14 & 90,00 & 84,50 & 89,49 & 82,24 & 82,86 \\
\hline 15 & 90,00 & 84,40 & 89,22 & 82,58 & 82,69 \\
\hline 16 & 90,00 & 84,00 & 89,20 & 82,66 & 82,23 \\
\hline 17 & 90,00 & 84,10 & 88,91 & 82,56 & 82,59 \\
\hline 18 & 90,00 & 84,00 & 88,61 & 82,33 & 83,27 \\
\hline 19 & 90,00 & 83,80 & 88,28 & 81,81 & 83,38 \\
\hline 20 & 90,00 & 83,70 & 88,35 & 81,68 & 83,48 \\
\hline 21 & 90,00 & 83,50 & 88,00 & 82,07 & 83,30 \\
\hline 22 & 90,00 & 83,00 & 87,93 & 84,62 & 82,76 \\
\hline 23 & 86,00 & 82,80 & 87,86 & 84,79 & 82,64 \\
\hline 24 & 90,00 & 83,30 & 88,15 & 84,96 & 83,48 \\
\hline 25 & 97,00 & 83,10 & 88,12 & 84,81 & 82,88 \\
\hline 26 & 98,00 & 82,80 & 87,68 & 84,24 & 83,48 \\
\hline 27 & 90,00 & 82,90 & 87,75 & 84,58 & 82,96 \\
\hline 28 & 90,00 & 82,60 & 87,26 & 84,78 & 83,96 \\
\hline 29 & 80,00 & 82,30 & 87,14 & 84,14 & 83,82 \\
\hline 30 & 86,00 & 81,70 & 87,48 & 84,90 & 83,57 \\
\hline 31 & 90,00 & 82,80 & 87,85 & 84,20 & 84,30 \\
\hline 32 & 90,00 & 83,60 & 87,26 & 85,00 & 85,11 \\
\hline 33 & 86,00 & 84,50 & 86,61 & 85,28 & 85,39 \\
\hline 34 & 90,00 & 85,40 & 85,88 & 85,24 & 86,29 \\
\hline 35 & 90,00 & 85,70 & 85,06 & 85,19 & 87,31 \\
\hline 36 & 90,00 & 85,50 & 84,13 & 84,87 & 87,80 \\
\hline 37 & 90,00 & 85,20 & 83,07 & 83,86 & 87,64 \\
\hline 38 & 90,00 & 85,10 & 82,80 & 83,69 & 88,23 \\
\hline 39 & 90,00 & 84,70 & 81,50 & 84,83 & 88,17 \\
\hline 40 & 70,00 & 83,40 & 83,40 & 85,27 & 87,18 \\
\hline 41 & 89,00 & 84,80 & 81,90 & 85,80 & 86,90 \\
\hline 42 & 90,00 & 85,30 & 81,40 & 85,44 & 85,56 \\
\hline 43 & 90,00 & 86,00 & 79,20 & 84,88 & 85,13 \\
\hline 44 & 90,00 & 86,80 & 82,00 & 87,00 & 84,43 \\
\hline 45 & 80,00 & 86,50 & 79,10 & 86,67 & 84,17 \\
\hline 46 & 90,00 & 85,80 & 77,80 & 86,00 & 83,00 \\
\hline 47 & 80,00 & 89,70 & 79,70 & 85,00 & 79,00 \\
\hline 48 & 90,00 & 90,00 & 83,00 & 83,33 & 76,67 \\
\hline 49 & 80,00 & 90,00 & 84,50 & 85,00 & 80,00 \\
\hline 50 & 80,00 & 90,00 & 89,00 & 80,00 & 80,00 \\
\hline
\end{tabular}

\begin{tabular}{cccccc}
\hline Mean & 87,96 & 84,72 & 86,56 & 83,97 & 83,56 \\
\hline Varian & 27,95 & 3,52 & 11,52 & 1,90 & 5,16 \\
\hline STDEV & 5,29 & 1,88 & 3,39 & 1,38 & 2,27 \\
\hline
\end{tabular}

Dapat di lihat melalui grafik:

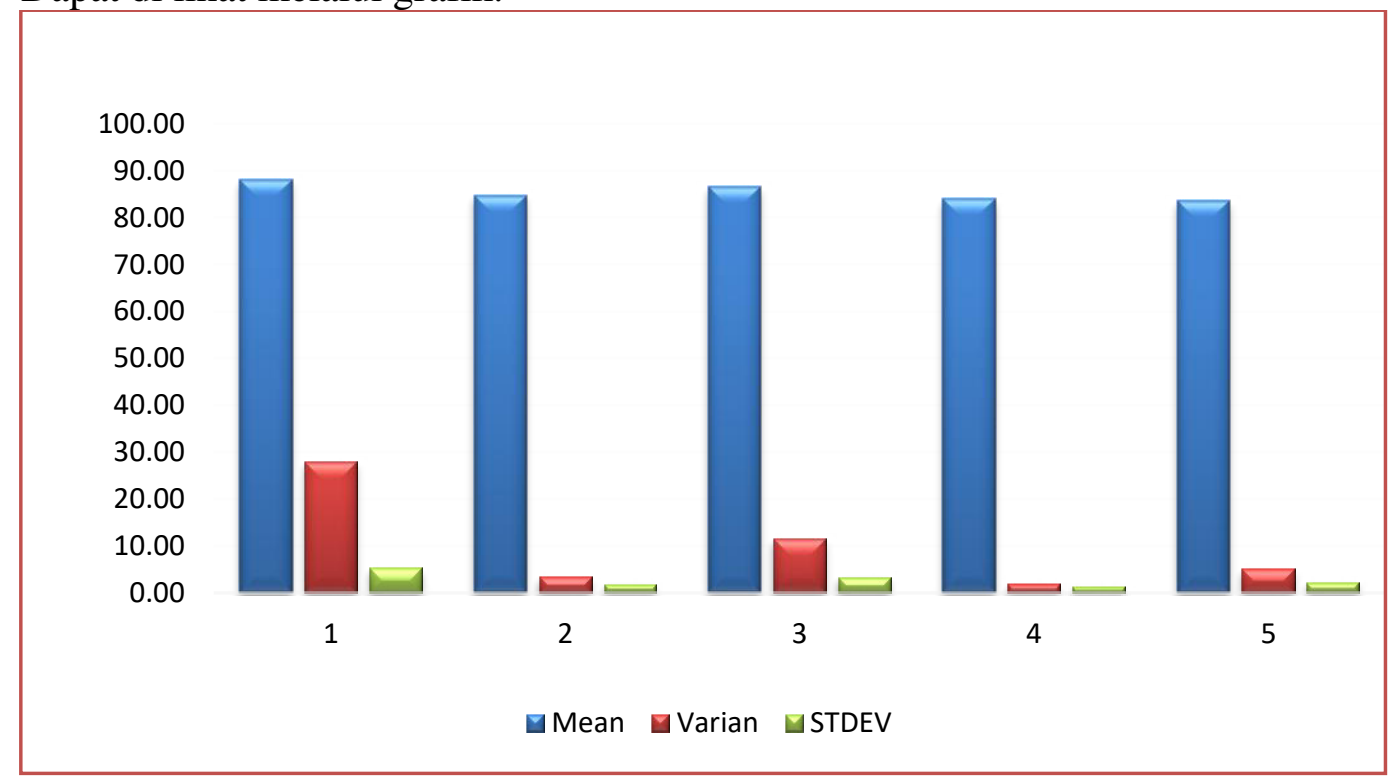


Data analisis di atas berdistribusi normal dan pembelajaran yang dilakukan dosen sangat membantu nilai UAS mahasiswa. Dapat dilihat dari data rata-rata nilai tertinggi adalah 87 pada matakuliah Bahasa Indonesia, dan rata-rata nilai terendah adalah 83 pada matakuliah psikologi pendidikan dan Perkembangan Pendidikan Anak Usia Dini. Kemampuan ini disebabkan oleh metode pembelajaran yang digunakan dosen sangat efisien dalam membantu mahasiswa dalam menyelesaikan masalah. Sehingga terbentuk keterampilan berpikir kritis untuk mendapatkan hasil maksimal. Matakuliah Psikologi berpengaruh terhadap matakuliah PPAUD, karena matakuliah ini berkaitan dengan perkembangan mendidik anak serta memahami tingkah laku anak dengan psikologi belajar. Antara matakuliah psikologi dan PPAUD terdapat keterkaitan.

Untuk membuktikan keterkaitan atau korelasi antara matakuliah maka berikut ini di jelaskan dalan hasil perhitungannya korelasi sebagai berikut:

Tabel 2. Perhitungan Korelasi antar Matakuliah

\begin{tabular}{|c|c|c|c|c|c|c|}
\hline \multirow{5}{*}{$\mathbf{R}$} & 1 & $\begin{array}{c}- \\
0,226362133\end{array}$ & 0,125245172 & $\begin{array}{c}- \\
0,069934895 \\
\end{array}$ & 0,093156652 & $\mathrm{x} 1$ \\
\hline & $\begin{array}{c}- \\
0,226362133 \\
\end{array}$ & 1 & $\begin{array}{c}- \\
0,452199524\end{array}$ & 0,006850351 & $\begin{array}{c}- \\
0,369406333\end{array}$ & $x 2$ \\
\hline & 0,125245172 & $\begin{array}{c}- \\
0,452199524 \\
\end{array}$ & 1 & $\begin{array}{c}- \\
0,666000212 \\
\end{array}$ & $\begin{array}{c}- \\
0,329596017 \\
\end{array}$ & $\mathrm{X3}$ \\
\hline & $\begin{array}{c}- \\
0,069934895 \\
\end{array}$ & 0,006850351 & $\begin{array}{c}- \\
0,666000212 \\
\end{array}$ & 1 & 0,402582657 & $x 4$ \\
\hline & 0,093156652 & $\begin{array}{c}- \\
0,369406333 \\
\end{array}$ & $\begin{array}{c}- \\
0,329596017 \\
\end{array}$ & 0,402582657 & 1 & $x 5$ \\
\hline
\end{tabular}

\section{Tabel Korelasi Antar Mata kuliah}

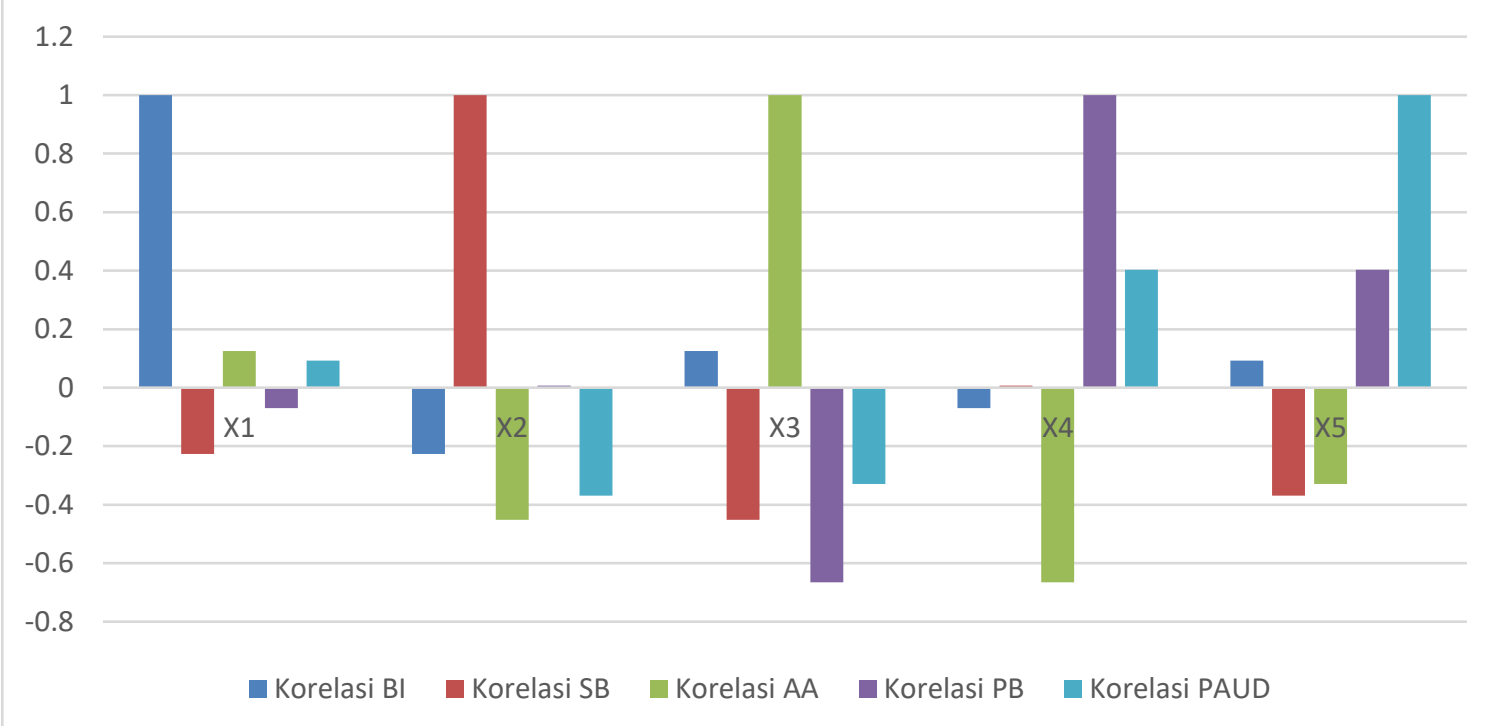

Keteramgan:

Keterangan

$\mathrm{X} 1=$ Nilai rata-rata $\mathrm{BI}$

$\mathrm{X} 2$ = Nilai Rata-rata $\mathrm{SB}$

$\mathrm{X} 3$ = Nilai rata-rata $\mathrm{AA}$

$\mathrm{X} 4$ = Nilai rata-rata $\mathrm{PB}$

X5 = Nilai Rata-rata PPAUD

Pada table perhitungan Korelasi di atas antara ke lima matakuliah memiliki korelasi namun tidak signifikan, sementara matakuliah X3, X4 dan X5 tidak terjalin kolerasi 
diantaranya, X3 berdiri sendiri dari tahun ketahun dengan variasi nilai. X1 akan tetap memiliki korelasi dengan matakuliah yang lain dari tahun ke tahun walaupun memiliki nilai distribusi rendah.

\begin{tabular}{cccccc}
\hline \multicolumn{7}{c}{ Sumarry Numbers } \\
\hline MIN & 70,00 & 81,70 & 77,80 & 80,00 & 76,67 \\
\hline Q1 & 89,25 & 83,63 & 84,22 & 83,05 & 82,55 \\
\hline MEDIAN & 90,00 & 84,55 & 87,89 & 84,00 & 82,98 \\
\hline Q3 & 90,00 & 85,18 & 89,15 & 84,95 & 84,40 \\
\hline MAX & 98,00 & 90,00 & 90,10 & 87,00 & 88,23 \\
\hline RANGE & 28,00 & 8,30 & 12,30 & 7,00 & 11,56 \\
\hline dQ & 0,75 & 1,55 & 4,92 & 1,90 & 1,85 \\
\hline
\end{tabular}

Keterangan :

Dari hasil perolehan hasil pengolahan data diperoleh data sebagai berikut: Nilai Minimal dari ke lima matakulian X1 =70, 00, X2 81, 70, X2 =77, 80, X3 = 80,00, dan X5 76,67. Titik skor dari distribusi Q1: 89, 83, 84, 83 dan 82. Nilai Median dari Urutan nilai terbesar sampai terkecil: $X 1=90, X 2=84, X 3=87, X 4=84, X 5=82$. Titik skor dari distribusi Q3 memiliki nilai: 90, 85, 98, 84, 84. Nilai maximal dari nilai keseluruhan: 98, 90, 90, 87, dan 88. Nilai Range: 28,00, 8,30, 12,30,7,00 dan 11,56. Nilai distribusi Q1 dan Q2 adalah dQ $=0,75,1,55,4,92,1,90$, dan 1,85 .

\section{PENUTUP}

Data UAS t/a 2013-2019, dari lima matakuliah memiliki nilai tertinggi di matakuliah Akidah Akhlak dan Bahasa Indonesia, yaitu memiliki nilai 98,00. Dengan standart deviasi yang lebih kecil yaitu 0,75. Sedangkan nilai rata-rata terendah 76,67 PPAUD. Mengingat matakuliah MKU tidak berkaitan dengan matakuliah Agama, dan Universitas Alwashliyah Medan adalah Universitas yang mengutamakan matakuliah Agama (Akidah Akhlak) maka Matakuliah MKU dengan MKA kurang terjadi keterkaitan antara satu sama lain. Maka tingkat kemampuan berpikir kritis mahasiswa lebih tinggi di matakuliah MKA daripada MKU.

\section{DAFTAR PUSTAKA}

Amalia, E., Surya, E., \& Syahputra, E. (2017). The Effectiveness Of Using Problem Based Learning (Pbl) In Mathematics Problem Solving Ability For Junior High School Students. Ijariie-Issn(O)-2395-4396, 3(2), 3402-3406. www.ijariie.com Aziz, A. (2015). Peningkatan Mutu Pendidikan. Jurnal Studi Islam Peningkatan Mutu. Darmadi, H. (2015). Tugas, Peran, Kompetensi, dan Tanggung Jawab Menjadi Guru Profesional. Pendidikan.

Ghozali, I. (2013). Aplikasi Analisis Multivariete Dengan Program IBM SPSS 23, Edisi 8. In Badan Penerbit Universitas Diponegoro.

Hasratuddin, H. (2013). Meningkatkan Kemampuan Berpikir Kritis Siswa Smp Melalui Pendekatan Matematika Realistik. Jurnal Pendidikan Matematika, 4(2).

Kahar, M. S. (2018). Assesmen Portofolio untuk Meningkatkan Hasil Belajar Fisika. Jurnal Edukasi Matematika Dan Sains. https://doi.org/10.25273/jems.v5i2.1987

Santoso, S. (2018). Mengusai statistik dengan SPPS 20. Book.

Tabrani, R. (1989). Pendekatan Dalam Proses Belajar Mengajar. Bandung: Remaja Karya.

Untersucher, D., Variablen, B., Interventionsprojekt, N., Tabelle, D., \& Therapie, O. (1988). - Der Zusammenhang von zwei und mehr Variablen -.

Wasikin Haryanti, E. H. (2017). Profil Pedagogical Content Knowledge Mahasiswa Calon Guru Biologi. BIOMA Jurnal Ilmiah Biologi. 